\title{
Tributo ao Instituto de Nutrição Josué de Castro da UFRJ 75 anos de história
}

\section{Tribute to the Instituto de Nutrição Josué de Castro at UFRJ- 75 years of history}

O presente editorial anuncia, neste número da revista, três manuscritos com o relato das realizações e conquistas do Instituto de Nutrição Josué de Castro (INJC), da Universidade Federal do Rio de Janeiro, no ensino de graduação, pós-graduação e extensão, ao longo de seus 75 anos de criação (1946-2021), como unidade formadora e produtora de conhecimento.

Tendo como fundador e primeiro diretor o ilustre professor Josué de Castro, e como missão principal o ensino, implantado em 1948 com a instalação do curso de dietistas, o INJC participou ativamente, em 2009, da criação do segundo curso de Nutrição da UFRJ, no campus Macaé Professor Aloísio Teixeira e, em 2011, implantou o curso de Gastronomia.

O ensino de graduação tem forte vínculo com as atividades de extensão, as quais demonstram forte compromisso com as demandas sociais.

O INJC é pioneiro ao sediar dois programas de pós-graduação congregando cursos de mestrado acadêmico, mestrado profissional e doutorado, com linhas de pesquisa em parcerias intra e interinstitucionais e com instituições internacionais.

Toda essa trajetória é contada, com maior riqueza de detalhes, nos manuscritos que tratam, ainda, das perspectivas e desafios das atividades-fins dessa que é uma das mais tradicionais instituições públicas universitárias, em níveis regional e nacional, na área de Alimentação e Nutrição.

O corpo social do INJC, por ocasião das comemorações do jubileu de brilhante da instituição, orgulhase de sua história de lutas e vitórias conquistadas mesmo diante das adversidades, vivenciadas pela educação pública em diferentes tempos, e reitera seu compromisso com a memória de seu patrono e com a saúde e bem-estar da sociedade brasileira.

Agradecemos à equipe editorial da DEMETRA pela oportunidade de contar essa vitoriosa história.

E que venham muitos outros jubileus para celebrar!

Avany Fernandes Diretora do Instituto de Nutrição Josué de Castro da UFRJ 